\title{
Additional and Different Application of the Bilobed Flap: Bilobed in Bilobed Flap for Reconstruction of the Lower-Upper Lid and Lateral Canthal Defects
}

I. M. Emsen

Published online: 2 July 2009

(c) Springer Science+Business Media, LLC and International Society of Aesthetic Plastic Surgery 2009

Retraction to: Aesth Plast Surg (2008) 32:542-545

DOI 10.1007/s00266-008-9118-x

This article was retracted by the Editor-in-Chief as portions of it were originally published by H. Cologlu et al., Axial
Bilobed Superficial Temporal Artery Island Flap (Tulip Flap): Reconstruction of Combined Defects of the Lateral Canthus Including the Lower and Upper Eyelids. Plastic and Reconstructive Surgery, Volume 119, Number 7, June 2007, pp. 2080-2087.

The online version of the original article can be found under doi:10.1007/s00266-008-9118-x.

I. M. Emsen $(\bowtie)$

Department of Plastic, Reconstructive, and Aesthetic Surgery,

Numune State Hospital, Erzurum, Turkey

e-mail: ilterisemsen@hotmail.com 